Article

\title{
Towards Bacteria Counting in DI Water of Several Microliters or Growing Suspension Using Impedance Biochips
}

\author{
Mahdi Kiani ${ }^{1,2, *(D)}$, Astrid Tannert ${ }^{3,4}$, Nan Du ${ }^{1,3,5, *}$, Uwe Hübner ${ }^{3}\left(\mathbb{D}\right.$, Ilona Skorupa ${ }^{6}$, \\ Danilo Bürger ${ }^{1}\left(\mathbb{D}\right.$, Xianyue Zhao $^{1}$, Daniel Blaschke ${ }^{3,6}{ }^{\text {, Lars Rebohle }}{ }^{6}$, Charaf Cherkouk ${ }^{6}$, \\ Ute Neugebauer $^{3,4}$, Oliver G. Schmidt ${ }^{2,7}$ and Heidemarie Schmidt 1,3,5,* \\ 1 Department Nano Device Technology, Fraunhofer Institute for Electronic Nano Systems, \\ Technologie-Campus 3, 09126 Chemnitz, Germany; danilo.buerger@enas.fraunhofer.de (D.B.); \\ xianyue.zhao@enas.fraunhofer.de (X.Z.) \\ 2 Material Systems for Nanoelectronics, Chemnitz University of Technology, 09126 Chemnitz, Germany; \\ o.schmidt@ifw-dresden.de \\ 3 Leibniz Institute of Photonic Technology, Albert-Einstein-Str. 9, 07745 Jena, Germany; \\ Astrid.Tannert@leibniz-ipht.de (A.T.); uwe.huebner@leibniz-ipht.de (U.H.); \\ daniel.blaschke@leibniz-ipht.de (D.B.); ute.neugebauer@leibniz-ipht.de (U.N.) \\ 4 Center for Sepsis Control and Care, Jena University Hospital, Am Klinikum 1, 07747 Jena, Germany \\ 5 Institute for Solid State Physics, Friedrich Schiller University Jena, 07743 Jena, Germany \\ 6 Helmholtz-Zentrum Dresden-Rossendorf, Bautzner Landstraße 400, 01328 Dresden, Germany; \\ i.skorupa@hzdr.de (I.S.); 1.rebohle@hzdr.de (L.R.); c.cherkouk@hzdr.de (C.C.) \\ 7 Institute for Integrative Nanosciences IFW Dresden, Helmholtzstr. 20, 01069 Dresden, Germany \\ * Correspondence: mahdi.kiani@enas.fraunhofer.de (M.K.); nan.du@enas.fraunhofer.de (N.D.); \\ heidemarie.schmidt@leibniz-ipht.de (H.S.)
}

Received: 6 June 2020; Accepted: 18 July 2020; Published: 23 July 2020

\begin{abstract}
We counted bacterial cells of E. coli strain K12 in several-microliter DI water or in several-microliter PBS in the low optical density $(\mathrm{OD})$ range $(\mathrm{OD}=0.05-1.08)$ in contact with the surface of Si-based impedance biochips with ring electrodes by impedance measurements. The multiparameter fit of the impedance data allowed calibration of the impedance data with the concentration $c_{b}$ of the $E$. coli cells in the range of $c_{b}=0.06$ to $1.26 \times 10^{9}$ cells $/ \mathrm{mL}$. The results showed that for E. coli in DI water and in PBS, the modelled impedance parameters depend linearly on the concentration of cells in the range of $c_{b}=0.06$ to $1.26 \times 10^{9}$ cells $/ \mathrm{mL}$, whereas the OD, which was independently measured with a spectrophotometer, was only linearly dependent on the concentration of the E. coli cells in the range of $c_{b}=0.06$ to $0.50 \times 10^{9}$ cells $/ \mathrm{mL}$.
\end{abstract}

Keywords: bacterial cell counting; biochips; impedance spectroscopy; Escherichia coli; electrical equivalent circuit model

\section{Introduction}

The techniques used to count biological species can be categorized into physical and biological ones. Physical methods will yield a total (living and dead) microorganisms count [1], while biological methods only record living organisms. A routinely used and easy physical way to count bacteria cells is the measurement of optical density (OD) at $600 \mathrm{~nm}$ [2]. Since this method measures the turbidity, and thus the scatter of light rather than the absorption, Beer's law and the linear dependence of the OD on the cell number are only applicable in a certain narrow (usually highly diluted, i.e., $0.1<\mathrm{OD}<1.0$ ) range [3]. Thus, counting of biological species by OD measurements in a large concentration range 
produces some technical and interpretative problems because OD data saturate above a threshold concentration. Moreover, since the intensity reduction of the incident light due to scatter is highly dependent on the geometry of the instrumentation, OD values taken from the same suspension can differ by as much as a factor of 2, depending on the device used for measurement. For this reason, calibration of each device is required using suspensions with known cell numbers. Further parameters that might influence the reliability of OD measurements are changes in the scattering behavior of bacterial cells in different growth phases and under treatment with antibiotics, as well as ingredients of the growth medium, which change its refractive index [4]. To assess the exact number and species of bacteria in a suspension, the biological method of plate counting agar (PCA) [5] is used, which involves plating of serial dilutions of the relevant sample and counting the growing colonies on the next day. This method is very labor-intensive and time-consuming, giving results only after approximately $24 \mathrm{~h}$. Alternative adequate, physical methods (e.g., microfluidic impedance cytometer [6] and impedance biochips $[7,8]$ ) have been used to count and discriminate biomaterial cells on the basis of their dielectric and electrical properties $[9,10]$. Impedance spectroscopy is one of the techniques used for the rapid counting of bacterial and other biological species [11]. It uses the conductance changes for quantitative and qualitative assessments of microbial growth [12]. Impedance spectroscopy was first proposed as an alternative method to replace the plate count technique for rapid screening of microbial content by Cady (1978) [13]. In our previous work, we counted different microorganisms (i.e., Lysinibacillus sphaericus JG-A12, in deionized (DI) water [14] and yeast Saccharomyces cerevisiae in deionized (DI) water and in glucose solution [15]) using impedance measurements on impedance biochips, where several microliters of liquid with the biological species was filled in the ring electrode area of the impedance biochip. We showed that the measured impedance for high OD is significantly different and systematically changes if up to $5 \mu \mathrm{L}$ of the medium with or without microorganisms is added to $20 \mu \mathrm{L}$ DI medium $[14,15]$.

In the present work, we used the Eschericha coli (E. coli) strain K12 in the concentration range from $0.06 \times 10^{9}$ to $1.26 \times 10^{9}$ cells $/ \mathrm{mL}$ and investigated the countability of $E$. coli in several-microliter liquid using impedance biochips. Virulent strains of Gram-negative E. coli are the main causative organisms of urinary tract infections and of urosepsis. In addition, E. coli can also cause certain gastroenterological diseases and neonatal meningitis. Additionally, certain non-pathologic strains of $E$. coli, including $\mathrm{K} 12$, are utilized in a variety of biotechnological and molecular biological applications and also serve as model organisms for a number of microbiological studies. For many of these applications, the number of cells in a growing suspension has to be determined. Detection of bacterial cell density is also an issue in the characterization of pathological patient isolates, for instance when determining antibiotic susceptibility.

We counted heat-inactivated immobilized E. coli cells using impedance biochips already filled with $20 \mu \mathrm{L}$ of either DI water or PBS after adding 1,2,3,4, and $5 \mu \mathrm{L}$ of DI water or PBS, respectively; and after adding $1,2,3,4$, and $5 \mu \mathrm{L}$ of E. coli suspended in DI water or PBS, respectively. We counted heat-inactivated E. coli cells using impedance biochips in DI water or PBS by subsequently adding a small amount of sample solution to the chips filled with $20 \mu \mathrm{L}$ of solvent. The impedance change of the impedance biochips was measured, modeled, and correlated with the concentration of E. coli in the suspension.

\section{Materials and Methods}

\subsection{Preparation of Bacteria and $O D$ Measurements}

E. coli, strain K12 have been used to investigate the countability of bacteria of small concentration in a several-microliter suspension. To assess the exact number of bacteria in the suspension (colony forming units, CFU) ( $x$-axis in Figure 1$)$ and to correlate the bacteria concentration with OD ( $y$-axis in Figure 1), the PCA techniques were used for calibration. Therefore, E. coli K12 were cultivated overnight in tryptic soy broth (TSB, Carl Roth $\mathrm{GmbH}$ ) at $37^{\circ} \mathrm{C}$ while shaking with 160 revolutions per 
minute (rpm) under ambient air conditions. OD was determined at different dilutions of this overnight culture ranging from 1:2 to 1:200 in TSB in triplicate using the cuvette port of a microplate reader Spark ${ }^{\circledR} 20 \mathrm{M}$ (Tecan, Männedorf, Switzerland).

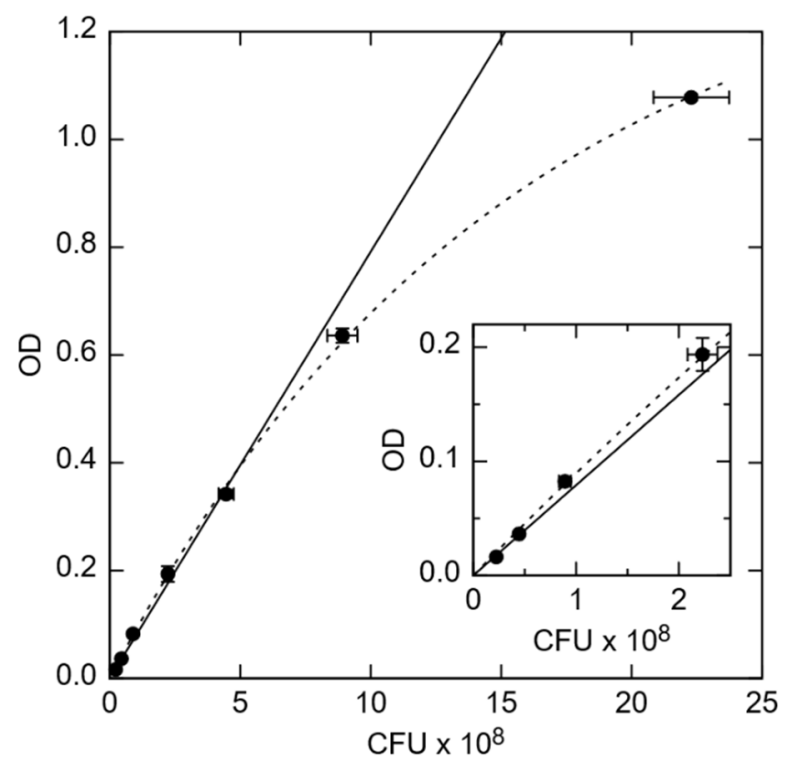

Figure 1. Optical density (OD) vs. colony-forming unit (CFU) counts of $E$. coli in units of $10^{8} / \mathrm{mL}$. (Inset) Zoomed in data in the OD range from 0.00 to 0.22 . The solid line is a linear extrapolation to larger cell concentrations, while the dashed line is an exponential fit to saturation at maximum. Error bars indicate the mean \pm standard deviation of 2 PCA measurements ( $x$-axis) and 3 OD measurements ( $y$-axis).

The amount of viable CFUs in the overnight cultured solution was determined by the PCA technique. Therefore, a solution of $\mathrm{OD}=0.1$ was diluted to a concentration corresponding 1:10 and $1: 10^{6}$ in duplicate, respectively. Then, $100 \mu \mathrm{L}$ of each dilution was plated onto an agar plate and cultivated at $37^{\circ} \mathrm{C}$ overnight. Visible colonies were counted the next day. The OD depends linearly on the concentration of E. coli in the OD range from about 0.015 to 0.34 , corresponding to 0.22 to $2.3 \times 10^{8} \mathrm{CFU} / \mathrm{mL}$, respectively. The optical density was determined at a 1:10 dilution in TSB in duplicate to determine the cell count. One microliter of the bacterial suspension was centrifuged at 13,000 xG for $90 \mathrm{~s}$, the bacterial pellet was washed once in Dulbecco's phosphate buffered saline (PBS, Merck Biochrome), and then resuspended in $1 \mathrm{~mL}$ PBS. Bacteria were heat-inactivated at $95{ }^{\circ} \mathrm{C}$ for at least $30 \mathrm{~min}$. Heat-inactivated E. coli were washed twice in PBS diluted 1:2 in DI water $(0.5 \times$ PBS) and resuspended in $0.5 \times$ PBS to about $12.5 \times 10^{8}$ (low concentration) or $63 \times 10^{8}$ cells $/ \mathrm{mL}$ (moderate concentration).

\subsection{Structural Description}

To fabricate the BS (boron-implanted Samples) impedance biochips boron ions (B) were implanted into Si:P, and to fabricate the PS (Phosphorus-implanted Samples) impedance biochips phosphorus (P) ions were implanted into Si:B (Table 1). Figure 2a,b show the structures of the BS and PS impedance biochips, respectively. Approximately 150-nm-thick gold ( $\mathrm{Au}$ ) layers were deposited by DC magnetron sputtering on silicon wafers measuring $525 \mu \mathrm{m}$ in thickness, while unstructured gold (Au) formed the bottom contact. Au ring electrodes with inner and outer diameters of $5.7 \mathrm{~mm}$ and $7.8 \mathrm{~mm}$, respectively, were fabricated using a lift-off process. 
Table 1. Implantation parameters of phosphorus-implanted (phosphorus into Si:B) PS biochip and of boron-implanted (boron into Si:P) BS biochip. The Au ring top electrodes and unstructured Au bottom contacts were prepared after ion implantation.

\begin{tabular}{cccc}
\hline Biochip & Implanted Ion & Ion Energy (MeV) & Ion Fluence (cm-2) \\
\hline PS & Phosphorus & 1.00 & $3 \times 10^{13}$ \\
BS & Boron & 0.45 & $3 \times 10^{13}$ \\
\hline
\end{tabular}

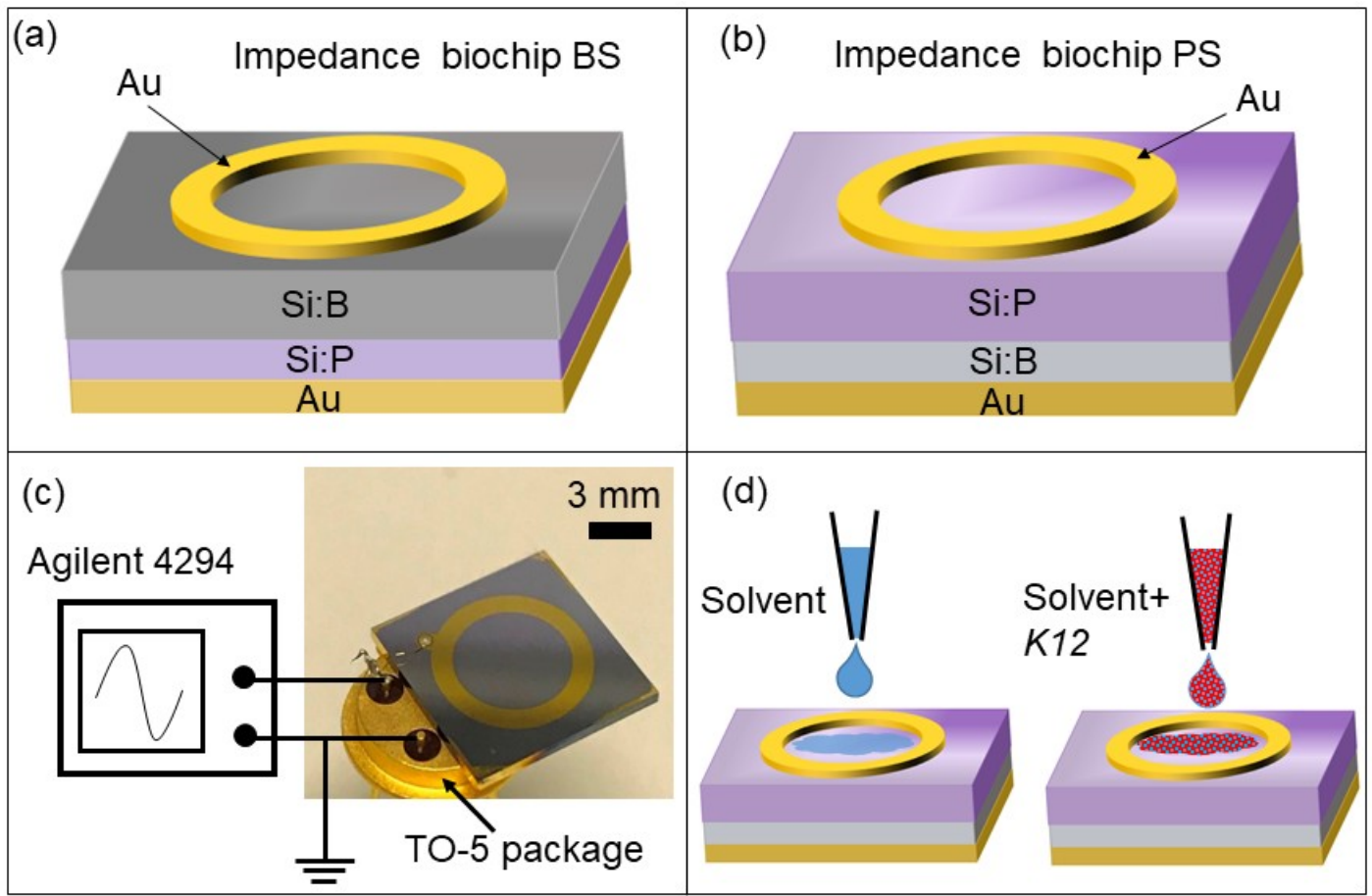

Figure 2. Schematic sketch of the (a) BS and (b) PS impedance biochips with a ring top electrode and with (a) boron ions (B) implanted into Si:P or with (b) phosphorus (P) ions implanted into Si:B. The top and bottom electrodes were wire-bonded to the pins of a TO-5 (Transistor Outline with base diameter of $8.9 \mathrm{~mm}$ ) package (c) and connected to an Agilent 4294A impedance analyzer. A several-microliter solvent (i.e., DI water or PBS) and E. coli cells were added into the top ring electrode and the impedance of the biochip was measured.

A ring electrode was selected because of the homogenous field distribution between the ring top electrode and unstructured bottom electrode [16]. The detection limit for a small number of cells in a liquid by impedance measurements using the Si biochip strongly depends on the volume of liquid for which the top electrode structure is optimized.

The presented ring electrode structure was optimized with respect to the inner and outer ring diameters to sense suspension volumes between 10 and $30 \mu \mathrm{L}$. Dependent on the concentrations of the implanted dopants, the impedance biochips without liquid filling have a pn junction (boundary between a p-type and n-type semiconductor) capacitance and a capacitance for the Schotty contact formed by the Au ring electrode. The capacitances of the $\mathrm{p}+\mathrm{n}$ junction in BS and of the $\mathrm{n}+\mathrm{p}$ junction in PS amount to $4.8 \times 10^{-9} \mathrm{~F}$ and $2.49 \times 10^{-9} \mathrm{~F}$, respectively. The capacitances of the Schottky contact formed by the Au ring electrodes on BS and PS amount to $3.12 \times 10^{-7} \mathrm{~F}$ and $4.49 \times 10^{-8} \mathrm{~F}$, respectively. If a smaller suspension volume was detected, the inner and outer diameters of the ring electrodes would have to be reduced. The standard TO-5 package (Figure 2c) was used to assemble the impedance biochip and measurement setup. The top and bottom contacts of the biochips were bonded to the pins of this package and an Agilent 4294A precision impedance analyzer was utilized to record the impedance characteristics of the biochips by sweeping the frequency from $40 \mathrm{~Hz}$ to $1 \mathrm{MHz}$ 
under normal daylight at room temperature. This impedance analyzer works in a range covering $10^{-3}$ to $10^{8} \mathrm{Ohm}$ and is suitable for impedance spectroscopy of the investigated Si biochips with impedance changes observed in the range from $10^{1} \mathrm{Ohm}$ up to $10^{5} \mathrm{Ohm}$. Before any measurement, the network analyzer was calibrated by performing 3 steps, namely shortcut, open circuit, and $50 \mathrm{Ohm}$ calibration. Typically, one frequency sweep lasts 30 s, i.e., if the impedance data are calibrated with the cell concentration, impedance measurements for cell counting can be performed in less than $1 \mathrm{~min}$. We chose two media liquids and added either DI water solvent and the E. coli or PBS solvent and E. coli into the gold ring top electrode region.

\subsection{Modelling}

During impedance measurements, a small alternating current (AC) test signal of $50 \mathrm{mV}$ was applied to BS and PS impedance biochips, while the complex resistance, i.e., the impedance, was measured for different test frequencies and plotted in the form of a Nyquist plot. This measurement technique is named impedance spectroscopy $(\operatorname{ImS})$ [17]. The change of the recorded impedance data was correlated with the independently determined cell concentration (Figure 1). ImS helps to detect biological species in contact with the surface of the impedance biochip, because those biological species change the impedance of impedance biochips in the area inside the ring electrodes. The corresponding electrical equivalent circuit is obtainable based on the electrical properties from the recorded Nyquist plots of the biochips without and with E. coli K12 cells [18]. A Nyquist plot reveals the contribution of different components in the equivalent circuit [19]. As an example, an imperfect semicircle is correlated with constant phase elements (CPE) [20]. In the physical structure of the biochip, the capacitance and resistance are associated with space charge polarization regions and with adsorption of $E$. coli in the area inside the electrode. Usually, most of the structures with electrodes contain a geometrical capacitance and a bulk resistance in parallel to it [21-23]. For the used BS and PS biochips, the bulk capacitance of the $\mathrm{p}-\mathrm{n}$ junction depletion region and the capacitance of the Schottky contacts between electrodes and semiconductor are modeled with resistor and capacitor pair [20]. To model the equivalent circuit parameters from the electrical equivalent circuit, complex non-linear least square (CNLS) software was used. Based on the Nyquist plot of the biochips. in which there are two imperfect semicircles, the electrical equivalent circuit shown in Figure $3 b$ for the BS biochip and in Figure $4 b$ for the PS biochip were selected [24,25].

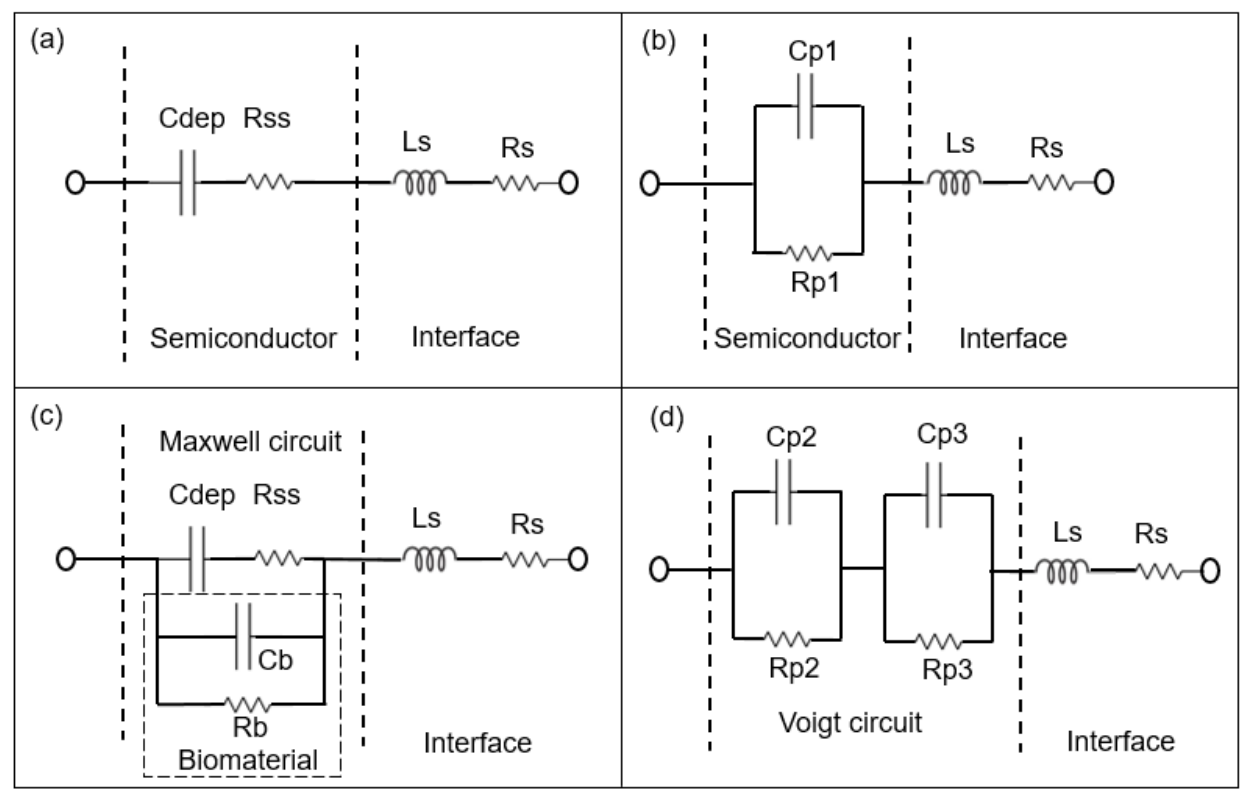

Figure 3. Schematic sketch of the equivalent circuit models of the BS biochip, where the capacitance of the Schottky contact formed by the Au ring electrode can be neglected without analyte (a) based on the 
physiochemical structure of the biochip and (b) based on the associated RC (Resistor and Capacitor) pairs. The parallel capacitor (Cp1) and parallel resistor (Rp1) can be transferred from Cdep (depletion capacitor) and Rss (semiconductor resistor) $\mathrm{Cb}$ and $\mathrm{Rb}$ corresponds to capacitive and resistive parts of biomaterial respectively. Cdep, Rss, $\mathrm{Cb}$ and $\mathrm{Rb}$ are transferred to the Parallel capacitor $\mathrm{Cp} 2$ and Cp3 and parallel resistor Rp2 na Rp3 from Equivalent circuit models of biochips with analyte in a (c) to Maxwell circuit and in a (d) Voigt circuit [14]. Ls and Rs are series inductor and resistor of the interface respectively.

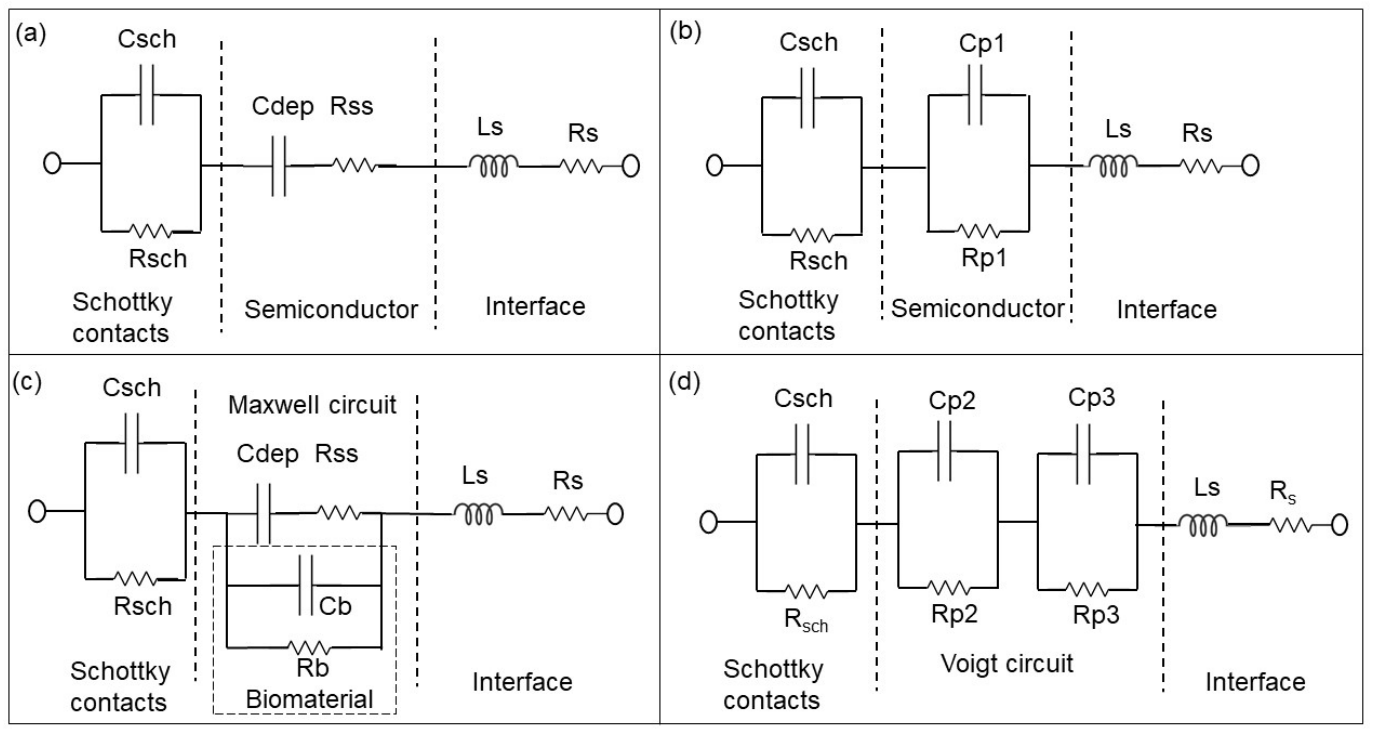

Figure 4. Equivalent circuit models of PS biochips (a) without solvent and bacteria and (b) based on the associated RC pairs. Equivalent circuit models of PS biochips with solvent or bacteria (c) and RC pairs (d) in Voigt fashion [14].

The Rp2-Cp2 and Rp3-CP3 pairs in Figures 3d and 4d correspond to the impedance of the pn junction below the Au ring electrode and below the contact formed by the liquid. Rsch and Csch describe the capacitance of the PS biochip due to the Schottky contact formed by the Au ring electrode (Figure 4c,d). The capacitance of the Schottky contact formed by the Au ring electrode (Figure 3c,d) on the BS biochip can be neglected. The Nyquist plot of the BS biochip without analyte consists of one semicircle. This semicircle can be represented by an associated resistor (R) and capacitor (C) pair, which is shown in Figure 3b. From the other side, the physical structures of the biochips consist of a $\mathrm{p}+\mathrm{n}$ - junction at the boundary between $\mathrm{p}+$ and $\mathrm{n}$-type silicon. A depletion region is formed at the interface of these two semiconductor types, consisting of Cdep and Rss (Figure 3a,c). Thus, the BS biochip can be described by the introduced model in Figure 3a. This model can be transferred to electrical equivalent circuit shown in the Figure $3 b$ by converting the series structures of Cdep and Rss to the parallel Cp1//Rp1 (Figure 3b), where Cp1 $=$ Cdep $\cdot\left(Q^{2} /\left(1+Q^{2}\right)\right), \operatorname{Rp} 1=\operatorname{Rss} \cdot\left(1+Q^{2}\right)$ with $\mathrm{Q}=1 /(\omega \cdot$ Cdep $\cdot$ Rss $)[26]$

The Nyquist plot for the PS biochip without liquid, however, reveals two non-overlapping semicircles and a resistor-capacitor (RC) pair. These semicircles are due to the $n+p$ - junction and the Schottky contacts that formed at the interfaces between Au top and bottom electrodes and the semiconductor. These metal-semiconductor Schottky contacts can be represented by an extra CPE and resistor pair in the electrical equivalent circuit [27] in Figure 4. The physiochemical model of the PS biochip, which is shown in Figure $4 \mathrm{a}$, can then be transferred into Figure $4 \mathrm{~b}$ by using series to parallel circuit exchange equations. After the DI water or PBS with E. coli is applied to the ring top electrode of the BS and PS biochips, an additional semicircle appears in the Nyquist plot. This semicircle 
is directly related to the cell concentration. In the electrical equivalent circuit with inserted liquid and with inserted liquid and E. coli in Figures $3 \mathrm{~d}$ and $4 \mathrm{~d}$, respectively, an additional $\mathrm{R}_{3} \mathrm{C}_{3}$ pair is used for modeling. This electrical modeling circuit needs to be equal to the physiochemical model. To transfer these two models, we employed two equivalent circuits that were equal at any frequencies. The Maxwell circuit in Figures $3 \mathrm{c}$ and $4 \mathrm{c}$ can be transferred into the Voigt circuit, as illustrated in Figures $3 \mathrm{~d}$ and $4 \mathrm{~d}$.

In brief, the impedance change, which is dependent on the bacterial concentration, was modeled with 4 parameters, Rp2, Cp2, Rp3, and CP3. In a future work we will develop another model approach to fit the $\mathrm{Cb}$ and $\mathrm{Rb}$ of the liquid and of the liquid with the biomaterial directly in the Maxwell circuit. The parameters Rp2, Cp2, Rp3, and Cp3 depend on Cdep, Rss, Cb, and Rb. Therefore, a multiparameter is needed to quantify the concentrations of E. coli cells by using the BS and PS biochips (Table 1).

The electrical equivalent circuit model of the BS impedance biochip with no medium and no bacteria consists of a CPE in parallel with a resistor (Figure 3b), while the electrical equivalent circuit for BS biochips BS with medium and with E. coli cells consists of two pairs of CPEs and resistors (Figure 3b). The PS biochip without analyte is modeled using two pairs of CPEs in parallel with resistors (Figure 4 b), while for the PS biochips with medium and with E. coli cells the circuit consists of three pairs of CPEs and resistors (Figure 4c). The equivalent circuit parameters Rs and Ls contribute to the lead impedances. Note that the equivalent circuit model shown in Figure $3 \mathrm{~b}$ for the BS biochip and Figure $4 \mathrm{c}$ for the PS biochip were applied to model impedance changes of the BS and PS biochips after adding $1,2,3,4$, and $5 \mu \mathrm{L}$ of medium with bacteria at low $\left(0.06\right.$ to $0.25 \times 10^{9}$ cells $\left./ \mathrm{mL}\right)$ and moderate concentrations $\left(0.29\right.$ to $1.26 \times 10^{9}$ cells $\left./ \mathrm{mL}\right)$.

\section{Results and Discussion}

E. coli cells were kept in DI water- $0.5 \times \mathrm{PBS}$ at cell concentrations of $\mathrm{c}_{\mathrm{b}}=0.06$ to $0.25 \times 10^{9}$ cells $/ \mathrm{mL}$ (low concentration range, Figure $5 b, d, j, 1)$, and at cell concentrations of $c_{b}=0.29$ to $1.26 \times 10^{9}$ cells $/ \mathrm{mL}$ (moderate concentration range, Figure $5 f, h, n, p)$. The impedance changes of PS and BS biochips were studied under the same experimental conditions without any analyte in the area inside the top of the ring electrode, shown as black thick curves in Figure 5 (no filling). We used four BS impedance biochips and PS four impedance biochips (indicated by blue boxes for results with DI water and red boxes for $0.5 \times$ PBS in Figure 5). Impedance data in the same box were obtained by performing reference measurements without $E$. coli cells and measurements with $E$. coli cells on the same impedance biochip. First, we added $20 \mu \mathrm{L}$ liquid without $E$. coli cells, plus $1,2,3,4$, and $5 \mu \mathrm{L}$ liquid without $E$. coli cells on a given impedance biochip. After letting $25 \mu \mathrm{L}$ of the liquid evaporate, the impedance of the impedance biochip without filling was remeasured and $20 \mu \mathrm{L}$ liquid without $E$. coli was added and remeasured. Then, we added $1,2,3,4$, and $5 \mu \mathrm{L}$ liquid with $E$. coli cells and measured the impedance. Note that the impedance of the biochips after evaporation of the liquid with E. coli cells is not the same as the impedance of the biochips after evaporation of the liquid without $E$. coli cells. The impedance values of biochips after adding $20 \mu \mathrm{L}$ DI water without $E$. coli cells are shown in Figure $5 \mathrm{a}, \mathrm{b}, \mathrm{e}, \mathrm{f}, \mathrm{i}, \mathrm{j}, \mathrm{m}, \mathrm{n}$; and after adding $20 \mu \mathrm{L} 0.5 \times$ PBS without $E$. coli cells are shown in Figure $5 \mathrm{c}, \mathrm{d}, \mathrm{g}, \mathrm{h}, \mathrm{k}, \mathrm{l}, \mathrm{o}, \mathrm{p}$. The impedance values of biochips after adding 1-5 $\mu \mathrm{L}$ DI water without $E$. coli cells are shown in Figure 5a,e,j,m; and after adding 1-5 $\mu \mathrm{L} 0.5 \times$ PBS without E. coli cells are shown in Figure $5 c, g, k, 0$. Every filling step and corresponding impedance measurement lasted $1 \mathrm{~min}$. Impedance values after adding $1-5 \mu \mathrm{L} 0.5 \times$ PBS with E. coli cells to $20 \mu \mathrm{L}$ DI water are shown in Figure $5 b, \mathrm{f}, \mathrm{j}, \mathrm{n}$; and with $20 \mu \mathrm{L} 0.5 \times$ PBS are shown in Figure 5d,h,l,p. Because of the different results for the impedance characteristics of the biochips with different media (e.g., Figure $5 a, c$ ), one can deduce that both biochips can be used to distinguish between these different media, namely DI water and 0.5 $\times$ PBS, which is not possible with an optical microscope. Additionally, and more importantly, the impedance biochips can also be used to count adsorbed cells. Adsorbed cells cause a significant change in the impedance of the biochips. The impedance characteristics of the biochips with DI water or 0.5× PBS and the corresponding impedance characteristics of the biochips with E. coli (Figure 5) confirm the significant sensitivity of 
the biochips to adsorbed E. coli cells in the area inside the ring electrode. Remarkably, an additional significant semicircle forms in the impedance plot of the biochips with added E. coli. This additional semicircle is pointed out by an arrow in Figure $5 b, d, f, h, j, 1, n, p$. We modeled the experimental impedance data and analyzed the modeled equivalent circuit parameters dependent on the filling of the area inside the ring electrode. The equivalent circuits for the biochips with DI water/0.5 $\times$ PBS and for the BS biochip with dispensed E. coli in DI water/0.5× PBS are shown in Figure 3a,b, respectively.

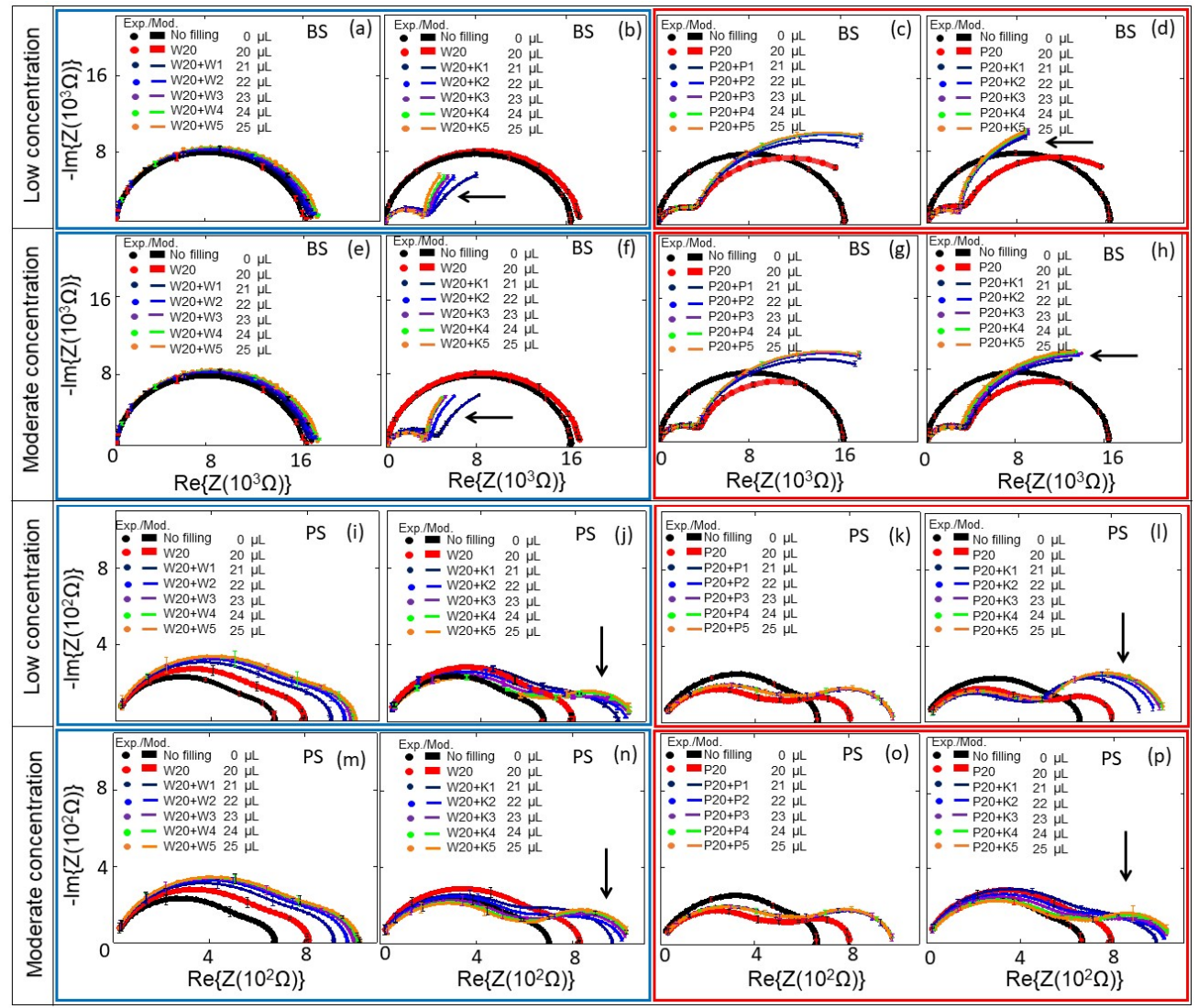

Figure 5. Experimental (symbols) and modeled (solid lines) Nyquist plots of the (a-h) BS and (i-p) PS biochips with no filling (black symbols and lines) and with $20 \mu \mathrm{L}$ DI water/PBS (red symbols and lines), and with additional DI water/0.5× PBS with and without E. coli in steps of $1 \mu \mathrm{L}: 1 \mu \mathrm{L}$ (Navy), $2 \mu \mathrm{L}$ (blue), $3 \mu \mathrm{L}$ (violet), $4 \mu \mathrm{L}$ (green), and $5 \mu \mathrm{L}$ (orange). Here, $1 \mu \mathrm{L}$ of $E$. coli and $5 \mu \mathrm{L}$ of $E$. coli respectively correspond to bacterial cell concentrations of $0.06 \times 10^{9} / \mathrm{mL}$ in $21 \mu \mathrm{L}$ medium and $0.25 \times 10^{9} / \mathrm{mL}$ in $25 \mu \mathrm{L}$ medium for low concentrations; and of $0.29 \times 10^{9} / \mathrm{mL}$ in $21 \mu \mathrm{L}$ medium and to $1.26 \times 10^{9} / \mathrm{mL}$ in $25 \mu \mathrm{L}$ medium for moderate concentrations. The significant additional semicircles in the Nyquist plots, which are caused by the E. coli, are indicated by arrows. In the plots, blue boxes represent the results with DI water and red boxes represent the results $0.5 \times$ PBS. W represents DI water, $\mathrm{P}$ is short for $0.5 \times$ PBS, K stands for $E$. coli K12, and the numbers represent the volumes in microliters; the total volumes of the liquids on the top electrode are mentioned in the legend in microliters. The standard deviation error bars for 3 repeated measurements are also added to the measurement points.

Without solvent and bacteria, the equivalent circuit consists of two imperfect capacitors or CPEs (Cp1, Cp2), two parallel resistors (Rp1, Rp2), a contact resistor (Rs), and a contact inductor (Ls). The modeled impedance circuit parameters are listed in Appendix A Tables A1-A12. The equivalent circuits of the impedance spectra of the biochips with and without E. coli cells are different due to the additional appearance of the semicircles, which are indicated by arrows in Figure 5.

Accordingly, based on the experimental impedance characteristics of the biochips after adding analyte, the composition and cell numbers of the E. coli added to the biochips can be determined by 
modeling the parameters of the equivalent circuit shown in Figure $3 b$ for the BS biochip, which consists of two imperfect capacitors (Cp1, Cp2); and those shown in Figure 4b for the PS biochip, which consists of three imperfect capacitors (Cp1, Cp2, Cp3) and three resistors (Rp1, Rp2, Rp3), a contact resistor (Rs), and a contact inductor (Ls).

The corresponding ImS modeling results of the biochips based on Tables A1-A8 are shown in Figure 6.The E. coli cell concentration was determined by measuring the OD of a diluted stock solution and calculating the corresponding number of cells using the calibration data from Figure 1. Observed impedance changes can be related to concentrations of E. coli cells for low concentrations $\left(0.06 \times 10^{9}\right.$ to $\left.0.25 \times 10^{9} / \mathrm{mL}\right)$ and moderate concentrations $\left(0.29\right.$ to $\left.1.26 \times 10^{9} / \mathrm{mL}\right)$. The modeled equivalent circuit elements Rp2, Rp3, Cp2, and Cp3 depend linearly on the concentration of E. coli cells. There is a linear relationship with the nominal number of bacterial cells extracted for the biochips with low concentrations $\left(0.06 \times 10^{9} / \mathrm{mL}\right.$ to $\left.0.25 \times 10^{9} / \mathrm{mL}\right)$ and with moderate concentrations $\left(0.29 \times 10^{9} / \mathrm{mL}\right.$ to $\left.1.26 \times 10^{9} / \mathrm{mL}\right)$. The modeling parameters Rp1 and Cp1 represent the Schottky contact at the electrode-semiconductor interface. If the size of the contact area is denoted as A, by adding the E. coli suspension to the top electrode region of the biochips, the effective area of the top contact is increased based on the equation $\operatorname{Rp} 2=\rho(d / A)$, where d denotes the thickness of the Schottky barrier and the resistance is reversely related to area A. Thus, there is a reduction in resistance Rp2 by adding the bacterial suspension. If we consider $\mathrm{Cp} 2=\varepsilon(\mathrm{A} / \mathrm{d})$, with $\varepsilon$ as the permittivity of the semiconductor, the relationship between $\mathrm{Cp} 2$ and $\mathrm{A}$ results in an increasing $\mathrm{Cp} 2$ with the increasing number of $E$. coli in the suspension.

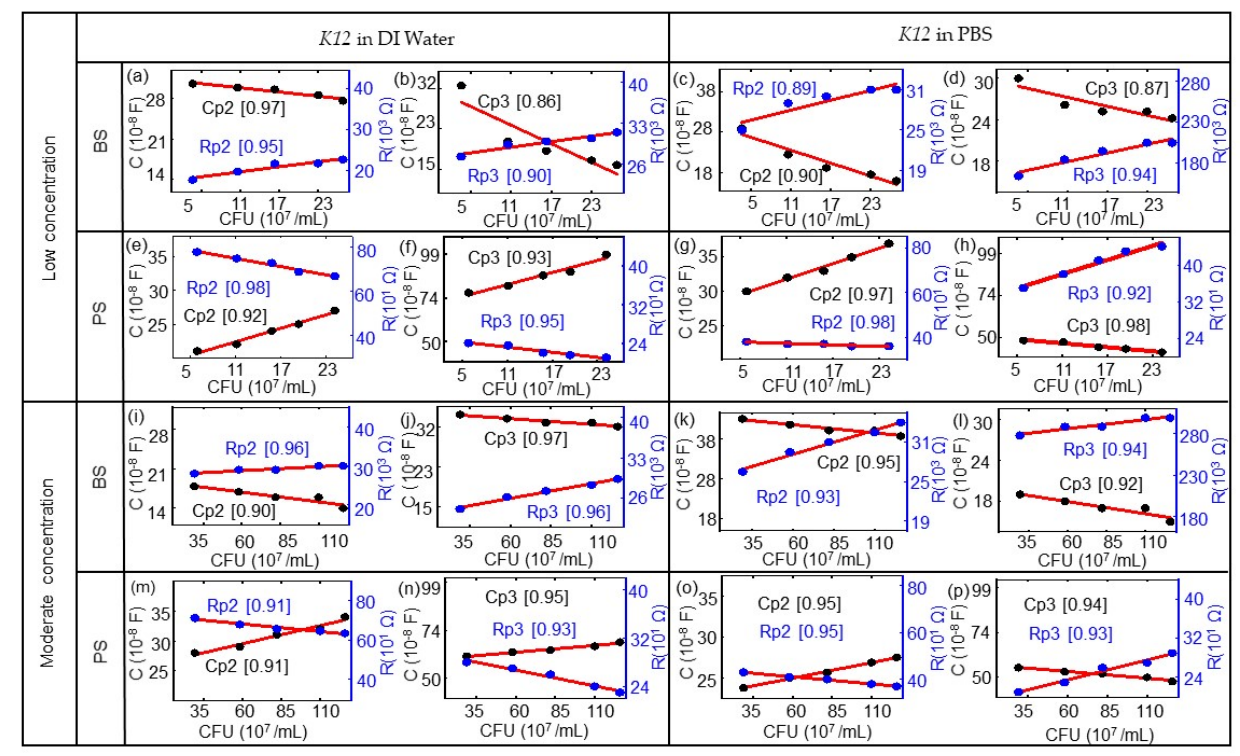

Figure 6. Modeled equivalent circuit parameters (dots) and linear fitting curves (red lines) for (a,c,e,g) Rp1 and Cp1 and for $(\mathbf{b}, \mathbf{d}, \mathbf{f}, \mathbf{h})$ Rp3 and CP3 for the BS biochip, dependent on the number of cells in $10^{7} / \mathrm{mL}$ in DI water or PBS. Modeled equivalent circuit parameters (dots) and linear fitting curves (red lines) for $(\mathbf{i}, \mathbf{k}, \mathbf{m}, \mathbf{o}) \mathrm{Rp} 1$ and Cp1 and for $(\mathbf{j}, \mathbf{l}, \mathbf{n}, \mathbf{p})$ Rp3 and CP3 for the PS biochip, dependent on the cell number in units of $10^{7} / \mathrm{mL}$ with the DI water and PBS media. The quality of the linear fitting was measured by the R-square or coefficient of determination (COD), as shown in the brackets for each data set. (This value is between 0 and 1 ; if the value is close to 1 , the relationship between a data point and a line will be regarded as very strong.).

\section{Conclusions}

We counted $E$. coli cells with concentrations from $c_{b}=0.06 \times 10^{9} / \mathrm{mL}$ to $c_{b}=1.26 \times 10^{9} / \mathrm{mL}$ in DI water and in PBS by analyzing the impedance of two different Si-based impedance biochips whose surfaces were in contact with the E. coli cells. Such impedance biochips are useful for disturbance-free 
monitoring of the cultivation of E. coli cells, providing significant time efficiency and high accuracy for a promising large range of cell concentrations. The significant changes between the impedance spectra before and after addition of the $E$. coli suspension into the top electrode region of the impedance biochips were evaluated. Developing a two-phase electrode structure helped to determine a proper equivalent circuit for the biochips with added bacteria. The modeling parameters Rp2, Cp2, Rp3, and Cp3 show the linear relationship with the E. coli cell number. Such linearly-dependent parameters were used to quantify the E. coli concentration. In comparison with impedance data, the dynamic range of OD data with respect to the cell concentration is smaller. OD data are only linear in the range of $0.06-0.5 \times 10^{9}$ cells $/ \mathrm{mL}$. In the future, detection of the dead and living biomaterials will be studied for different cell sizes and concentrations, and the further applications in microbiology, food industry, and medicine will be evaluated.

Author Contributions: Conceptualization: H.S. and U.N.; methodology: H.S., N.D., and D.B. (Danilo Bürger); software: M.K., and N.D.; validation: M.K.; formal analysis: M.K., A.T. and H.S.; investigation: M.K. and X.Z.; resources: U.H., A.T., I.S., L.R., C.C. and D.B. (Danilo Bürger); data curation: M.K.; writing-original draft preparation, M.K. and A.T.; writing-review and editing: H.S.; visualization: U.N. and D.B. (Daniel Blaschke); supervision: H.S.; project administration: H.S., U.N, and O.G.S.; funding acquisition: L.R., C.C., O.G.S., and H.S. All authors have read and agreed to the published version of the manuscript.

Funding: Funding by Sächsische Aufbaubank (SAB) (PolCarr-Sens project, grant number: 100260515), Bundesministerium für Wirtschaft und Energie (BMWi) (BASTION project, grant number: 03THW12K11), and by the DFG Core Facility "Jena Biophotonic and Imaging Laboratory" (JBIL, FKZ: PO 563/29-1, BA 1601/10-1) is gratefully acknowledged.

Conflicts of Interest: The authors declare no conflict of interest.

\section{Appendix A}

Table A1. Modeled impedance parameters Cp2, Rp2, Cp3, Rp3, Rs, and Ls of the BS biochip with DI water (Figure $3 \mathrm{~d}$ ). W20 + W0 $=20 \mu \mathrm{L}$ DI water, W20 + W1 $=21 \mu \mathrm{L}$ DI water, W20 + W2 $=2 \mu \mathrm{L}$ DI water, W20+ W3 $=23 \mu \mathrm{L}$ DI water, W20 + W4 $=24 \mu \mathrm{L}$ DI water, W20 + W5 $=25 \mu \mathrm{L}$ DI water, and Rs $=1.6 \times 10^{-9} \Omega$ and Ls $=2.6 \times 10^{-15} \mathrm{H}$. BS biochip without DI water (Figure $3 \mathrm{~b}$ ) Cp1=4.8 $\times 10^{-9} \mathrm{~F}$, $\mathrm{Rp} 1=1.6 \times 10^{4} \Omega, \mathrm{Rs}=1.6 \times 10^{-9} \Omega$, and $\mathrm{Ls}=2.6 \times 10^{-15} \mathrm{H}$. The calculated capacitance of the $\mathrm{p}-\mathrm{n}$ junction in BS amounts to $3.7 \times 10^{-9} \mathrm{~F}$, which is comparable to $\mathrm{CP} 1$.

\begin{tabular}{ccccc}
\hline Circuit Element & Cp2 (F) & Rp2 $(\Omega)$ & Cp3 (F) & Rp3 $(\Omega)$ \\
\hline BS + W20 + W0 & $6.2 \times 10^{-9}$ & $1.7 \times 10^{4}$ & $4.1 \times 10^{-7}$ & $1.31 \times 10^{4}$ \\
BS + W20 + W1 & $6.0 \times 10^{-9}$ & $1.9 \times 10^{4}$ & $4.3 \times 10^{-7}$ & $1.3 \times 10^{4}$ \\
BS + W20 + W2 & $5.9 \times 10^{-9}$ & $2.0 \times 10^{4}$ & $4.9 \times 10^{-7}$ & $1.4 \times 10^{4}$ \\
BS + W20 + W3 & $5.8 \times 10^{-9}$ & $2.1 \times 10^{4}$ & $5.5 \times 10^{-7}$ & $1.6 \times 10^{4}$ \\
BS + W20 + W4 & $5.7 \times 10^{-9}$ & $2.2 \times 10^{4}$ & $5.8 \times 10^{-7}$ & $1.8 \times 10^{4}$ \\
BS + W20 + W5 & $5.6 \times 10^{-9}$ & $2.3 \times 10^{4}$ & $6.0 \times 10^{-7}$ & $1.9 \times 10^{4}$ \\
\hline
\end{tabular}

Table A2. Modeled impedance parameters Cp2, Rp2, Cp3, Rp3, Rs, and Ls of the BS biochip with $\mathrm{DI}$ water and low-concentration $\mathrm{K} 12$ (Figure $5 \mathrm{~b}$ ). Here, $\mathrm{c}_{\mathrm{b}}=0.06 \times 10^{9}$ to $0.25 \times 10^{9}$ cells $/ \mathrm{mL}$, $\mathrm{Cp} 1=4.8 \times 10^{-9} \mathrm{~F}, \mathrm{Rp} 1=1.6 \times 10^{4} \Omega$, Rs $=1.6 \times 10^{-9} \Omega$, and Ls $=2.6 \times 10^{-15} \mathrm{H}$.

\begin{tabular}{ccccc}
\hline Circuit Element & Cp2 (F) & Rp2 $(\Omega)$ & Cp3 (F) & Rp3 $(\Omega)$ \\
\hline BS + W20 + W0 & $6.2 \times 10^{-9}$ & $1.7 \times 10^{4}$ & $4.1 \times 10^{-7}$ & $1.31 \times 10^{4}$ \\
BS + W20 + K1 & $3.1 \times 10^{-9}$ & $1.8 \times 10^{4}$ & $3.3 \times 10^{-7}$ & $2.4 \times 10^{4}$ \\
BS + W20 + K2 & $3.0 \times 10^{-9}$ & $2.0 \times 10^{4}$ & $2.1 \times 10^{-7}$ & $3.0 \times 10^{4}$ \\
BS + W20 + K3 & $3.0 \times 10^{-9}$ & $2.2 \times 10^{4}$ & $1.9 \times 10^{-7}$ & $3.0 \times 10^{4}$ \\
BS + W20 + K4 & $2.9 \times 10^{-9}$ & $2.2 \times 10^{4}$ & $1.7 \times 10^{-7}$ & $3.1 \times 10^{4}$ \\
BS + W20 + K5 & $2.8 \times 10^{-9}$ & $2.3 \times 10^{4}$ & $1.6 \times 10^{-7}$ & $3.2 \times 10^{4}$
\end{tabular}

$\mathrm{W} 20=20 \mu \mathrm{L}$ DI water, $\mathrm{K} 1=1 \mu \mathrm{L}$ K12 ( $\mathrm{c}_{\mathrm{b}}=0.06 \times 10^{9}$ cells $\left./ \mathrm{mL}\right), \mathrm{K} 2=2 \mu \mathrm{L}$ K12 ( $\mathrm{c}_{\mathrm{b}}=0.11 \times 10^{9}$ cell $\left.\mathrm{s} / \mathrm{mL}\right), \mathrm{K} 3=3$ $\mu \mathrm{LK12}\left(\mathrm{c}_{\mathrm{b}}=0.16 \times 10^{9}\right.$ cells $\left./ \mathrm{mL}\right), \mathrm{K} 4=4 \mu \mathrm{L}$ K12 $\left(\mathrm{c}_{\mathrm{b}}=0.21 \times 10^{9}\right.$ cells $\left./ \mathrm{mL}\right), \mathrm{K} 5=5 \mu \mathrm{L}$ K12 $\left(\mathrm{c}_{\mathrm{b}}=0.25 \times 10^{9}\right.$ cells $\left./ \mathrm{mL}\right)$. 
Table A3. Modeled impedance parameters Cp2, Rp2, Cp3, Rp3, Rs, and Ls of the BS biochip, with DI water and moderate-concentration $\mathrm{K} 12$ (Figure $5 \mathrm{f}$ ). here, $0.29 \times 10^{9}$ to $1.26 \times 10^{9}$ cells $/ \mathrm{mL}$, Rs $=1.6 \times 10^{-9} \Omega$, and Ls $=2.6 \times 10^{-15} \mathrm{H}$.

\begin{tabular}{ccccc}
\hline Circuit Element & Cp2 (F) & Rp2 $(\Omega)$ & Cp3 (F) & Rp3 $(\Omega)$ \\
\hline BS + W20 + W0 & $6.2 \times 10^{-9}$ & $1.7 \times 10^{4}$ & $4.1 \times 10^{-7}$ & $1.31 \times 10^{4}$ \\
BS + W20 + K1 & $3.0 \times 10^{-9}$ & $3.0 \times 10^{4}$ & $2.1 \times 10^{-7}$ & $3.4 \times 10^{4}$ \\
BS + W20 + K2 & $2.9 \times 10^{-9}$ & $3.2 \times 10^{4}$ & $2.0 \times 10^{-7}$ & $3.7 \times 10^{4}$ \\
BS + W20 + K3 & $2.8 \times 10^{-9}$ & $3.5 \times 10^{4}$ & $1.8 \times 10^{-7}$ & $3.8 \times 10^{4}$ \\
BS + W20 + K4 & $2.6 \times 10^{-9}$ & $4.2 \times 10^{4}$ & $1.7 \times 10^{-7}$ & $3.9 \times 10^{4}$ \\
BS + W20 + K5 & $2.5 \times 10^{-9}$ & $4.7 \times 10^{4}$ & $1.6 \times 10^{-7}$ & $4.0 \times 10^{4}$
\end{tabular}

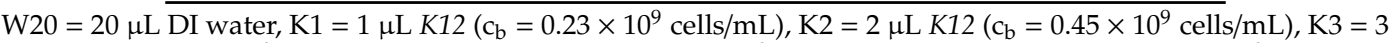
$\mu \mathrm{LK12}\left(\mathrm{c}_{\mathrm{b}}=0.65 \times 10^{9}\right.$ cells $\left./ \mathrm{mL}\right), \mathrm{K} 4=4 \mu \mathrm{L}$ K12 $\left(\mathrm{c}_{\mathrm{b}}=0.88 \times 10^{9}\right.$ cells $\left./ \mathrm{mL}\right), \mathrm{K} 5=5 \mu \mathrm{L}$ K12 $\left(\mathrm{c}_{\mathrm{b}}=1.26 \times 10^{9} \mathrm{cells} / \mathrm{mL}\right)$.

Table A4. Modeled impedance parameters Cp2, Rp2, Cp3, Rp3, Rs, and Ls of the BS biochip with PBS14 (Figure 5c), Rs $=1.6 \times 10^{-9} \Omega$, and Ls $=2.6 \times 10^{-15} \mathrm{H}$.

\begin{tabular}{ccccc}
\hline Circuit Element & Cp2 (F) & Rp2 $(\Omega)$ & Cp3 (F & Rp3 $(\Omega)$ \\
\hline BS + P20 + P0 & $2.0 \times 10^{-9}$ & $3.3 \times 10^{4}$ & $1.9 \times 10^{-7}$ & $2.4 \times 10^{4}$ \\
BS + P20 + P1 & $2.0 \times 10^{-9}$ & $3.3 \times 10^{4}$ & $2.2 \times 10^{-7}$ & $2.6 \times 10^{4}$ \\
BS + P20 + P2 & $2.1 \times 10^{-9}$ & $3.4 \times 10^{4}$ & $2.3 \times 10^{-7}$ & $2.7 \times 10^{4}$ \\
BS + P20 + P3 & $2.2 \times 10^{-9}$ & $3.4 \times 10^{4}$ & $2.4 \times 10^{-7}$ & $2.8 \times 10^{4}$ \\
BS + P20 + P4 & $2.3 \times 10^{-9}$ & $3.6 \times 10^{4}$ & $2.5 \times 10^{-7}$ & $2.9 \times 10^{4}$ \\
BS + P20 + P5 & $2.5 \times 10^{-9}$ & $3.7 \times 10^{4}$ & $2.7 \times 10^{-7}$ & $3.0 \times 10^{4}$
\end{tabular}

P20 $=20 \mu \mathrm{L}$ PBS14 varying analyte: P1 $=1 \mu \mathrm{L}$ PBS, P2 $=2 \mu \mathrm{L}$ PBS, P3 $=3 \mu \mathrm{L}$ PBS, P4 $=4 \mu \mathrm{L}$ PBS, P5 $=5 \mu \mathrm{L}$ PBS.

Table A5. Modeled impedance parameters Cp2, Rp2, Cp3, Rp3, Rs, and Ls of the BS biochip with PBS14 as the medium and low-concentration K12 (Figure $5 \mathrm{~d}$ ), $\mathrm{c}_{\mathrm{b}}=0.06 \times 10^{9}$ to $0.25 \times 10^{9}$ cells $/ \mathrm{mL}$, Rs $=1.6 \times 10^{-9} \Omega$, and Ls $=2.6 \times 10^{-15} \mathrm{H}$.

\begin{tabular}{ccccc}
\hline Circuit Element & Cp2 (F) & Rp2 $(\Omega)$ & Cp3 (F) & Rp3 $(\Omega)$ \\
\hline BS + P20 + P0 & $2.0 \times 10^{-9}$ & $3.3 \times 10^{4}$ & $1.9 \times 10^{-7}$ & $2.4 \times 10^{4}$ \\
BS + P20 + K1 & $2.5 \times 10^{-9}$ & $2.4 \times 10^{4}$ & $3.1 \times 10^{-7}$ & $1.8 \times 10^{4}$ \\
BS + P20 + K2 & $2.1 \times 10^{-9}$ & $2.8 \times 10^{4}$ & $2.7 \times 10^{-7}$ & $2.0 \times 10^{4}$ \\
BS + P20 + K3 & $1.9 \times 10^{-9}$ & $2.9 \times 10^{4}$ & $2.6 \times 10^{-7}$ & $2.1 \times 10^{4}$ \\
BS + P20 + K4 & $1.8 \times 10^{-9}$ & $3.0 \times 10^{4}$ & $2.6 \times 10^{-7}$ & $2.2 \times 10^{4}$ \\
BS + P20 + K5 & $1.7 \times 10^{-9}$ & $3.0 \times 10^{4}$ & $2.5 \times 10^{-7}$ & $2.2 \times 10^{4}$
\end{tabular}

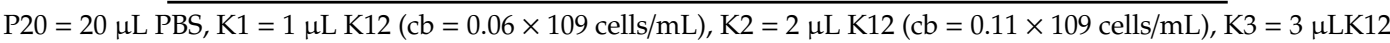
$(\mathrm{cb}=0.16 \times 109$ cells $/ \mathrm{mL}), \mathrm{K} 4=4 \mu \mathrm{L} \mathrm{K12}(\mathrm{cb}=0.21 \times 109$ cells $/ \mathrm{mL}), \mathrm{K} 5=5 \mu \mathrm{L}$ K12 $(\mathrm{cb}=0.25 \times 109$ cells $/ \mathrm{mL})$.

Table A6. Modeled impedance parameters Cp2, Rp2, Cp3, Rp3, Rs, and Ls of the BS biochip with PBS14 as the medium and moderate-concentration K12 (Figure $5 \mathrm{~h}$ ), $\mathrm{c}_{\mathrm{b}}=0.29 \times 10^{9}$ to $1.26 \times 10^{9} \mathrm{cells} / \mathrm{mL}$, Rs $=1.6 \times 10^{-9} \Omega$, and Ls $=2.6 \times 10^{-15} \mathrm{H}$.

\begin{tabular}{ccccc}
\hline Circuit Element & Cp2 (F) & Rp2 $(\Omega)$ & Cp3 (F) & Rp3 $(\Omega)$ \\
\hline BS + P20 + P0 & $2.0 \times 10^{-9}$ & $3.3 \times 10^{4}$ & $1.9 \times 10^{-7}$ & $2.4 \times 10^{4}$ \\
BS + P20 +K1 & $1.9 \times 10^{-9}$ & $2.8 \times 10^{4}$ & $3.8 \times 10^{-7}$ & $2.5 \times 10^{4}$ \\
BS + P20 +K2 & $1.8 \times 10^{-9}$ & $2.9 \times 10^{4}$ & $3.7 \times 10^{-7}$ & $2.7 \times 10^{4}$ \\
BS + P20 +K3 & $1.7 \times 10^{-9}$ & $2.9 \times 10^{4}$ & $3.6 \times 10^{-7}$ & $2.8 \times 10^{4}$ \\
BS + P20 +K4 & $1.7 \times 10^{-9}$ & $3.0 \times 10^{4}$ & $3.6 \times 10^{-7}$ & $2.9 \times 10^{4}$ \\
BS + P20 +K5 & $1.5 \times 10^{-9}$ & $3.0 \times 10^{4}$ & $3.5 \times 10^{-7}$ & $3.0 \times 10^{4}$ \\
\hline
\end{tabular}

P20 $=20 \mu \mathrm{L}$ PBS, K1 = $1 \mu \mathrm{L} \mathrm{K12} \mathrm{(cb} \mathrm{=} 0.23 \times 109$ cells $/ \mathrm{mL}), \mathrm{K} 2=2 \mu \mathrm{L} \mathrm{K12}(\mathrm{cb}=0.45 \times 109$ cells $/ \mathrm{mL}), \mathrm{K} 3=3 \mu \mathrm{LK} 12$ $(\mathrm{cb}=0.65 \times 109$ cells $/ \mathrm{mL}), \mathrm{K} 4=4 \mu \mathrm{L} \mathrm{K} 12(\mathrm{cb}=0.88 \times 109$ cells $/ \mathrm{mL}), \mathrm{K} 5=5 \mu \mathrm{L} \mathrm{K12}(\mathrm{cb}=1.26 \times 109$ cells $/ \mathrm{mL})$. 
Table A7. Modeled impedance parameters Cp2, Rp2, Csch, Rsch, Cp3, Rp3, Rs, and Ls of the PS biochip with added DI water: W20 + W0 $=20 \mu \mathrm{L}$ DI water, W20 + W5 $=25 \mu \mathrm{L}$ DI water (Figure 5i), Rs $=2.5 \times 10^{-8} \Omega$, and Ls $=2.6 \times 10^{-15} \mathrm{H}$. PS without DI water (Figure $4 \mathrm{~d}$ ). Csch $=1.19 \times 10^{-7} \mathrm{~F}$ and Rsch $=5.5 \times 10^{2} \Omega, C p 1=2.49 \times 10^{-9} \mathrm{~F}$ and $\mathrm{Rp} 1=5.5 \times 10^{2} \Omega$. The calculated capacitance of the $\mathrm{p}-\mathrm{n}$ junction in PS amounts to $6.8 \times 10^{-9} \mathrm{~F}$ and is comparable to CP1. The calculated capacitance of the Schottky contact in PS amounts to $4.49 \times 10^{-8} \mathrm{~F}$ and is comparable to Csch. Rs $=2.5 \times 10^{-8} \Omega$ and Ls $=2.6 \times 10^{-15} \mathrm{H}$.

\begin{tabular}{ccccccc}
\hline Circuit Element & Cp2 (F) & Rp2 $(\Omega)$ & Csch (F) & Rsch $(\Omega)$ & Cp3 (F) & Rp3 $(\Omega)$ \\
\hline PS + W20 + W0 & $5.9 \times 10^{-9}$ & $7.4 \times 10^{2}$ & $1.7 \times 10^{-7}$ & $5.5 \times 10^{2}$ & $2.2 \times 10^{-9}$ & $2.4 \times 10^{2}$ \\
PS + W20 + W1 & $5.7 \times 10^{-9}$ & $8.2 \times 10^{2}$ & $1.4 \times 10^{-7}$ & $5.5 \times 10^{2}$ & $1.9 \times 10^{-9}$ & $2.8 \times 10^{2}$ \\
PS + W20 + W2 & $5.5 \times 10^{-9}$ & $8.5 \times 10^{2}$ & $1.4 \times 10^{-7}$ & $5.5 \times 10^{2}$ & $1.7 \times 10^{-9}$ & $3.1 \times 10^{2}$ \\
PS + W20 + W3 & $5.4 \times 10^{-9}$ & $8.7 \times 10^{2}$ & $1.3 \times 10^{-7}$ & $5.4 \times 10^{2}$ & $1.6 \times 10^{-9}$ & $3.5 \times 10^{2}$ \\
PS + W20 + W4 & $5.2 \times 10^{-9}$ & $8.9 \times 10^{2}$ & $1.3 \times 10^{-7}$ & $5.4 \times 10^{2}$ & $1.5 \times 10^{-9}$ & $3.8 \times 10^{2}$ \\
PS + W20 + W5 & $5.0 \times 10^{-9}$ & $9.1 \times 10^{2}$ & $1.3 \times 10^{-7}$ & $5.4 \times 10^{2}$ & $1.2 \times 10^{-9}$ & $4.1 \times 10^{2}$ \\
\hline
\end{tabular}

W20 $=20 \mu \mathrm{L}$ DI water, W1 = $1 \mu \mathrm{L}$ DI water, W2 $=2 \mu \mathrm{L}$ DI water, W3 = $3 \mu \mathrm{L}$ DI water, W4 = $4 \mu \mathrm{L}$ DI water, $\mathrm{W} 5=5 \mu \mathrm{L}$ DI water.

Table A8. Modeled impedance parameters Cp2, Rp2, Csch, Rsch, Cp3, Rp3, Rs, and Ls of the PS biochip with DI water and low-concentration $\mathrm{K} 12$ (Figure 5j). Here, $\mathrm{c}_{\mathrm{b}}=0.06 \times 10^{9}$ to $0.25 \times 10^{9}$ cells $/ \mathrm{mL}$. Rs $=2.5 \times 10^{-8} \Omega$ and Ls $=2.6 \times 10^{-15} \mathrm{H}$.

\begin{tabular}{ccccccc}
\hline Circuit Element & Cp2 (F) & Rp2 $(\boldsymbol{\Omega})$ & Csch $(\mathbf{F})$ & Rsch $(\boldsymbol{\Omega})$ & Cp3 $(\mathrm{F})$ & Rp3 $(\boldsymbol{\Omega})$ \\
\hline PS + W20 + K0 & $5.9 \times 10^{-9}$ & $7.4 \times 10^{2}$ & $1.7 \times 10^{-7}$ & $5.5 \times 10^{2}$ & $2.2 \times 10^{-9}$ & $2.4 \times 10^{2}$ \\
PS + W20 + K1 & $2.1 \times 10^{-9}$ & $7.8 \times 10^{2}$ & $1.4 \times 10^{-7}$ & $5.5 \times 10^{2}$ & $7.8 \times 10^{-9}$ & $2.4 \times 10^{2}$ \\
PS + W20 + K2 & $2.2 \times 10^{-9}$ & $7.5 \times 10^{2}$ & $1.4 \times 10^{-7}$ & $5.5 \times 10^{2}$ & $8.2 \times 10^{-9}$ & $2.4 \times 10^{2}$ \\
PS + W20 + K3 & $2.4 \times 10^{-9}$ & $7.3 \times 10^{2}$ & $1.3 \times 10^{-7}$ & $5.4 \times 10^{2}$ & $8.8 \times 10^{-9}$ & $2.2 \times 10^{2}$ \\
PS + W20 + K4 & $2.5 \times 10^{-9}$ & $6.9 \times 10^{2}$ & $1.3 \times 10^{-7}$ & $5.4 \times 10^{2}$ & $9.0 \times 10^{-9}$ & $2.1 \times 10^{2}$ \\
PS + W20 + K5 & $2.7 \times 10^{-9}$ & $6.7 \times 10^{2}$ & $1.3 \times 10^{-7}$ & $5.4 \times 10^{2}$ & $10 \times 10^{-9}$ & $2.1 \times 10^{2}$ \\
\hline
\end{tabular}

W20 $=20 \mu \mathrm{L}$ DI water, $\mathrm{K} 1=1 \mu \mathrm{L} \mathrm{K12}(\mathrm{cb}=0.06 \times 109$ cells $/ \mathrm{mL}), \mathrm{K} 2=2 \mu \mathrm{L} \mathrm{K12}(\mathrm{cb}=0.11 \times 109$ cells $/ \mathrm{mL}), \mathrm{K} 3=3 \mu \mathrm{L}$ $\mathrm{K} 12(\mathrm{cb}=0.16 \times 109$ cells $/ \mathrm{mL}), \mathrm{K} 4=4 \mu \mathrm{L} \mathrm{K12}(\mathrm{cb}=0.21 \times 109$ cells $/ \mathrm{mL}), \mathrm{K} 5=5 \mu \mathrm{L} \mathrm{K12}(\mathrm{cb}=0.25 \times 109$ cells $/ \mathrm{mL})$.

Table A9. Modeled impedance parameters Cp2, Rp2, Csch, Rsch, Cp3, Rp3, Rs, and Ls of the PS biochip with DI water and moderate-concentration K12 (Figure 5n), where $c_{b}=0.29 \times 10^{9}$ to $1.26 \times 10^{9}$ cells $/ \mathrm{mL}$. Rs $=2.5 \times 10^{-8} \Omega$ and Ls $=2.6 \times 10^{-15} \mathrm{H}$.

\begin{tabular}{ccccccc}
\hline Circuit Element & Cp2 (F) & Rp2 $(\Omega)$ & Cpsch (F) & Rsch $(\Omega)$ & Cp3 (F) & Rp3 $(\Omega)$ \\
\hline PS + W20 + K0 & $5.9 \times 10^{-9}$ & $7.4 \times 10^{2}$ & $1.7 \times 10^{-7}$ & $5.5 \times 10^{2}$ & $2.2 \times 10^{-9}$ & $2.4 \times 10^{2}$ \\
PS + W20 + K1 & $2.8 \times 10^{-9}$ & $6.8 \times 10^{2}$ & $1.4 \times 10^{-7}$ & $5.5 \times 10^{2}$ & $6.1 \times 10^{-9}$ & $2.8 \times 10^{2}$ \\
PS + W20 + K2 & $2.9 \times 10^{-9}$ & $6.5 \times 10^{2}$ & $1.4 \times 10^{-7}$ & $5.5 \times 10^{2}$ & $6.3 \times 10^{-9}$ & $2.7 \times 10^{2}$ \\
PS + W20 + K3 & $3.1 \times 10^{-9}$ & $6.3 \times 10^{2}$ & $1.3 \times 10^{-7}$ & $5.4 \times 10^{2}$ & $6.4 \times 10^{-9}$ & $2.6 \times 10^{2}$ \\
PS + W20 + K4 & $3.2 \times 10^{-9}$ & $6.2 \times 10^{2}$ & $1.3 \times 10^{-7}$ & $5.4 \times 10^{2}$ & $6.6 \times 10^{-9}$ & $2.4 \times 10^{2}$ \\
PS + W20 + K5 & $3.4 \times 10^{-9}$ & $6.1 \times 10^{2}$ & $1.3 \times 10^{-7}$ & $5.4 \times 10^{2}$ & $6.8 \times 10^{-9}$ & $2.3 \times 10^{2}$ \\
\hline
\end{tabular}

W20 $=20 \mu \mathrm{L}$ DI water, $\mathrm{K} 1=1 \mu \mathrm{L}$ K12 (cb = $0.23 \times 109$ cells $/ \mathrm{mL}), \mathrm{K} 2=2 \mu \mathrm{L} \mathrm{K12}(\mathrm{cb}=0.45 \times 109 \mathrm{cells} / \mathrm{mL}), \mathrm{K} 3=3$ $\mu \mathrm{LK} 12(\mathrm{cb}=0.65 \times 109$ cells $/ \mathrm{mL}), \mathrm{K} 4=4 \mu \mathrm{L} \mathrm{K12}(\mathrm{cb}=0.88 \times 109$ cells $/ \mathrm{mL}), \mathrm{K} 5=5 \mu \mathrm{L} \mathrm{K12}(\mathrm{cb}=1.26 \times 109$ cells $/ \mathrm{mL})$.

Table A10. Modeled impedance parameters Cp2, Rp2, Csch, Rsch, Cp3, Rp3, Rs, and Ls of the PS biochip with PBS (Figure 5k). Rs $=2.5 \times 10^{-8} \Omega$ and Ls $=2.6 \times 10^{-15} \mathrm{H}$.

\begin{tabular}{ccccccc}
\hline Circuit Element & Cp2 (F) & Rp2 $(\boldsymbol{\Omega})$ & Cpsch $(F)$ & Rsch $(\boldsymbol{\Omega})$ & Cp3 $(\mathrm{F})$ & Rp3 $(\boldsymbol{\Omega})$ \\
\hline PS + P20 + P0 & $7.8 \times 10^{-9}$ & $4.7 \times 10^{2}$ & $2.7 \times 10^{-8}$ & $3.5 \times 10^{2}$ & $1.4 \times 10^{-7}$ & $2.8 \times 10^{2}$ \\
PS + P20 + P1 & $7.9 \times 10^{-9}$ & $6.8 \times 10^{2}$ & $1.4 \times 10^{-8}$ & $5.5 \times 10^{2}$ & $1.1 \times 10^{-9}$ & $3.4 \times 10^{2}$ \\
PS + P20 + P2 & $7.9 \times 10^{-9}$ & $6.7 \times 10^{2}$ & $1.4 \times 10^{-8}$ & $5.4 \times 10^{2}$ & $1.2 \times 10^{-9}$ & $3.4 \times 10^{2}$ \\
PS + P20 + P3 & $7.9 \times 10^{-9}$ & $6.7 \times 10^{2}$ & $1.4 \times 10^{-8}$ & $5.4 \times 10^{2}$ & $1.2 \times 10^{-9}$ & $3.4 \times 10^{2}$ \\
PS + P20 + P4 & $7.9 \times 10^{-9}$ & $6.7 \times 10^{2}$ & $1.4 \times 10^{-8}$ & $5.4 \times 10^{2}$ & $1.2 \times 10^{-9}$ & $3.4 \times 10^{2}$ \\
PS + P20 + P5 & $7.9 \times 10^{-9}$ & $6.7 \times 10^{2}$ & $1.4 \times 10^{-8}$ & $5.4 \times 10^{2}$ & $1.2 \times 10^{-9}$ & $3.4 \times 10^{2}$ \\
\hline
\end{tabular}

P20 $=20 \mu \mathrm{L}$ PBS with varying analyte levels: P1 $=1 \mu \mathrm{L}$ PBS, P2 $=2 \mu \mathrm{L}$ PBS, P3 $=3 \mu \mathrm{L}$ PBS, P4 $=4 \mu \mathrm{L}$ PBS, $\mathrm{P} 5=5 \mu \mathrm{L}$ PBS. 
Table A11. Modeled impedance parameters Cp2, Rp2, Csch, Rsch, Cp3, Rp3, Rs, and Ls of the PS biochip with PBS14 and low-concentration K12 (Figure 5l), $\mathrm{c}_{\mathrm{b}}=0.06 \times 10^{9}$ to $0.25 \times 10^{9} \mathrm{cells} / \mathrm{mL}$. Rs $=2.5 \times 10^{-8} \Omega$ and Ls $=2.6 \times 10^{-15} \mathrm{H}$.

\begin{tabular}{ccccccc}
\hline Circuit Element & Cp2 (F) & Rp2 $(\Omega)$ & Cpsch (F) & Rsch $(\Omega)$ & Cp3 $(F)$ & Rp3 $(\Omega)$ \\
\hline PS + P20 + K0 & $7.8 \times 10^{-9}$ & $4.7 \times 10^{2}$ & $2.7 \times 10^{-8}$ & $3.5 \times 10^{2}$ & $1.4 \times 10^{-7}$ & $2.8 \times 10^{2}$ \\
PS + P20 + K1 & $3.0 \times 10^{-9}$ & $3.8 \times 10^{2}$ & $1.4 \times 10^{-7}$ & $5.5 \times 10^{2}$ & $4.8 \times 10^{-9}$ & $3.5 \times 10^{2}$ \\
PS + P20 + K2 & $3.2 \times 10^{-9}$ & $3.7 \times 10^{2}$ & $1.3 \times 10^{-7}$ & $5.4 \times 10^{2}$ & $4.7 \times 10^{-9}$ & $3.8 \times 10^{2}$ \\
PS + P20 + K3 & $3.3 \times 10^{-9}$ & $3.7 \times 10^{2}$ & $1.3 \times 10^{-7}$ & $5.4 \times 10^{2}$ & $4.4 \times 10^{-9}$ & $4.1 \times 10^{2}$ \\
PS + P20 + K4 & $3.5 \times 10^{-9}$ & $3.6 \times 10^{2}$ & $1.3 \times 10^{-7}$ & $5.4 \times 10^{2}$ & $4.3 \times 10^{-9}$ & $4.3 \times 10^{2}$ \\
PS + P20 + K5 & $3.7 \times 10^{-9}$ & $3.6 \times 10^{2}$ & $1.4 \times 10^{-7}$ & $5.5 \times 10^{2}$ & $4.1 \times 10^{-9}$ & $4.4 \times 10^{2}$ \\
\hline
\end{tabular}

P20 = $20 \mu \mathrm{L}$ PBS, K1 = $1 \mu \mathrm{L}$ K12 (cb = $0.06 \times 109$ cells $/ \mathrm{mL}), \mathrm{K} 2=2 \mu \mathrm{L}$ K12 (cb = $0.11 \times 109$ cells $/ \mathrm{mL}), \mathrm{K} 3=3 \mu \mathrm{L}$ K12 $(\mathrm{cb}=0.16 \times 109$ cells $/ \mathrm{mL}), \mathrm{K} 4=4 \mu \mathrm{L} \mathrm{K12}(\mathrm{cb}=0.21 \times 109$ cells $/ \mathrm{mL}), \mathrm{K} 5=5 \mu \mathrm{L}$ K12 $(\mathrm{cb}=0.25 \times 109$ cells $/ \mathrm{mL})$.

Table A12. Modeled impedance parameters Cp2, Rp2, Csch, Rsch, Cp3, Rp3, Rs, and Ls of the PS biochip with PBS14 and moderate-concentration K12 (Figure 5p), $\mathrm{c}_{\mathrm{b}}=0.29 \times 10^{9}$ to $1.26 \times 10^{9}$ cells $/ \mathrm{mL}$. Rs $=2.5 \times 10^{-8} \Omega$ and Ls $=2.6 \times 10^{-15} \mathrm{H}$.

\begin{tabular}{ccccccc}
\hline Circuit Element & Cp2 (F) & Rp2 $(\Omega)$ & Cpsch (F) & Rsch $(\Omega)$ & Cp3 $(F)$ & Rp3 $(\Omega)$ \\
\hline PS + P20 + K0 & $7.8 \times 10^{-9}$ & $4.7 \times 10^{2}$ & $2.7 \times 10^{-8}$ & $3.5 \times 10^{2}$ & $1.4 \times 10^{-7}$ & $2.8 \times 10^{2}$ \\
PS + P20 + K1 & $1.8 \times 10^{-9}$ & $4.3 \times 10^{2}$ & $1.4 \times 10^{-7}$ & $5.5 \times 10^{2}$ & $5.5 \times 10^{-9}$ & $2.9 \times 10^{2}$ \\
PS + P20 + K2 & $2.0 \times 10^{-9}$ & $4.1 \times 10^{2}$ & $1.4 \times 10^{-7}$ & $5.5 \times 10^{2}$ & $5.3 \times 10^{-9}$ & $2.7 \times 10^{2}$ \\
PS + P20 + K3 & $2.1 \times 10^{-9}$ & $4.0 \times 10^{2}$ & $1.3 \times 10^{-7}$ & $5.4 \times 10^{2}$ & $5.2 \times 10^{-9}$ & $2.6 \times 10^{2}$ \\
PS + P20 + K4 & $2.3 \times 10^{-9}$ & $3.8 \times 10^{2}$ & $1.3 \times 10^{-7}$ & $5.4 \times 10^{2}$ & $5.0 \times 10^{-9}$ & $2.3 \times 10^{2}$ \\
PS + P20 + K5 & $2.4 \times 10^{-9}$ & $3.7 \times 10^{2}$ & $1.3 \times 10^{-7}$ & $5.4 \times 10^{2}$ & $4.8 \times 10^{-9}$ & $2.1 \times 10^{2}$ \\
\hline
\end{tabular}

P20 $=20 \mu \mathrm{L}$ PBS, K1 = $1 \mu \mathrm{L}$ K12 ( $\mathrm{c}_{\mathrm{b}}=0.23 \times 10^{9}$ cells $\left./ \mathrm{mL}\right), \mathrm{K} 2=2 \mu \mathrm{L} \mathrm{K12}\left(\mathrm{c}_{\mathrm{b}}=0.45 \times 10^{9} \mathrm{cells} / \mathrm{mL}\right), \mathrm{K} 3=3 \mu \mathrm{LK} 12$ $\left(c_{b}=0.65 \times 10^{9}\right.$ cells $\left./ \mathrm{mL}\right), \mathrm{K} 4=4 \mu \mathrm{L} K 12\left(c_{b}=0.88 \times 10^{9}\right.$ cells $\left./ \mathrm{mL}\right), \mathrm{K} 5=5 \mu \mathrm{L} \mathrm{K12}\left(\mathrm{c}_{\mathrm{b}}=1.26 \times 10^{9} \mathrm{cells} / \mathrm{mL}\right)$.

\section{Appendix B}

Table A13. The impedance amplitudes for the boron-doped BS biochip with low-concentration K12 at $40 \mathrm{~Hz}, 400 \mathrm{~Hz}$, and $4 \mathrm{kHz}$ (Figure A1).

\begin{tabular}{cccc}
\hline & $|\mathrm{Z}|(\Omega) @ \mathbf{4 0 ~} \mathbf{H z}$ & $|\mathrm{Z}|(\Omega) @ \mathbf{4 0 0} \mathbf{H z}$ & $|\mathrm{Z}|(\Omega) @ \mathbf{4 0 0 0} \mathbf{H z}$ \\
\hline BS + W20 + K1 & 17956 & 16325 & 8732 \\
$\mathrm{BS}+\mathrm{W} 20+\mathrm{K} 2$ & 17202 & 16088 & 8425 \\
$\mathrm{BS}+\mathrm{W} 20+\mathrm{K} 3$ & 16871 & 15851 & 8321 \\
$\mathrm{BS}+\mathrm{W} 20+\mathrm{K} 4$ & 16689 & 15122 & 8258 \\
BS + W20 + K5 & 16198 & 14712 & 8104
\end{tabular}

$\mathrm{W} 20=20 \mu \mathrm{L}$ DI water, $\mathrm{K} 1=1 \mu \mathrm{L}$ E. coli $(\mathrm{cb}=0.06 \times 109 / \mathrm{mL}), \mathrm{K} 2=2 \mu \mathrm{L}$ E. coli $(\mathrm{cb}=0.11 \times 109 / \mathrm{mL}), \mathrm{K} 3=3 \mu \mathrm{L}$ E. Coli $(\mathrm{cb}=0.16 \times 109 / \mathrm{mL}), \mathrm{K} 4=4 \mu \mathrm{L}$ E. coli $(\mathrm{cb}=0.21 \times 109 / \mathrm{mL}), \mathrm{K} 5=5 \mu \mathrm{L}$ E. coli $(\mathrm{cb}=0.25 \times 109 / \mathrm{mL})$.

Table A14. The impedance amplitude for the PS biochip with low-concentration $K 12$ at $40 \mathrm{~Hz}, 400 \mathrm{~Hz}$, and $4 \mathrm{kHz}$. (Figure A1).

\begin{tabular}{cccc}
\hline & $|Z|(\Omega) @ \mathbf{4 0 ~ H z}$ & $|Z|(\Omega) @ \mathbf{4 0 0 ~ H z}$ & $|Z|(\Omega) @ \mathbf{4 0 0 0 ~ H z}$ \\
\hline PS + W20 +K1 & 820 & 805 & 768 \\
PS + W20 +K2 & 812 & 796 & 761 \\
PS + W20 +K3 & 804 & 789 & 752 \\
PS + W20 +K4 & 796 & 783 & 748 \\
PS + W20 +K5 & 790 & 778 & 741 \\
\hline
\end{tabular}

$\mathrm{W} 20=20 \mu \mathrm{L}$ DI water, $\mathrm{K} 1=1 \mu \mathrm{L}$ E. coli $\left(\mathrm{c}_{\mathrm{b}}=0.06 \times 10^{9}\right.$ cells $\left./ \mathrm{mL}\right), \mathrm{K} 2=2 \mu \mathrm{L}$ E. coli $\left(\mathrm{c}_{\mathrm{b}}=0.11 \times 10^{9} / \mathrm{mL}\right), \mathrm{K} 3=3 \mu \mathrm{LE}$. $\operatorname{coli}\left(\mathrm{c}_{\mathrm{b}}=0.16 \times 10^{9} / \mathrm{mL}\right), \mathrm{K} 4=4 \mu \mathrm{L}$ E. coli $\left(\mathrm{c}_{\mathrm{b}}=0.21 \times 10^{9} / \mathrm{mL}\right), \mathrm{K} 5=5 \mu \mathrm{L}$ E. coli $\left(\mathrm{c}_{\mathrm{b}}=0.25 \times 10^{9} / \mathrm{mL}\right)$. 
(a)

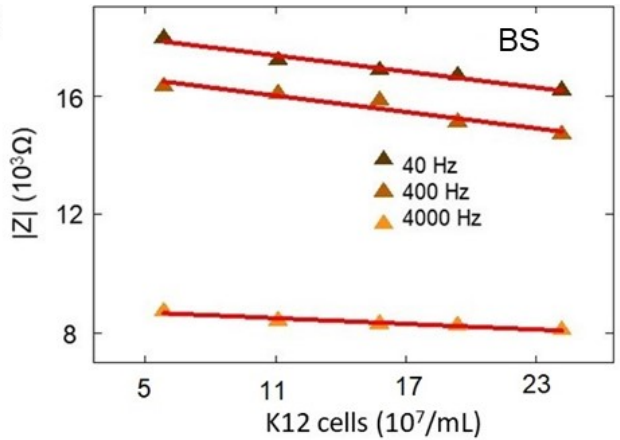

(b)

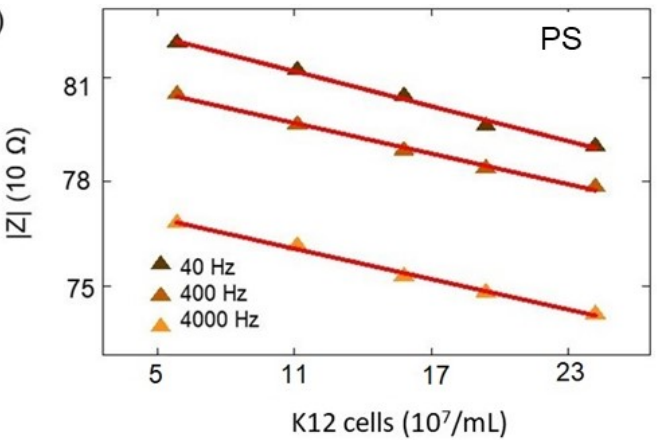

Figure A1. Impedance measured at test frequencies of $40 \mathrm{~Hz}, 400 \mathrm{~Hz}$, and $4000 \mathrm{~Hz}$ on (a) BS (Table A13) and (b) PS (Table A14) biochips, dependent on the number of low-concentration K12 bacteria and under normal illumination.

\section{References}

1. Turano, A.; Pirali, F. Quantification Methods in Microbiology. In Laboratory Diagnosis of Infectious Diseases; Springer Science and Business Media LLC: Berlin/Heidelberg, Germany, 1988; pp. 8-13.

2. Stevenson, K.; McVey, A.F.; Clark, I.B.N.; Swain, P.S.; Pilizota, T. General calibration of microbial growth in microplate readers. Sci. Rep. 2016, 6, 38828. [CrossRef] [PubMed]

3. Meredith, W.J.; Massey, J.B. Fundamental Physics of Radiology; Butterworth-Heinemann: Oxford, UK, 1977.

4. Bereiter-Hahn, J.; Fox, C.H.; Thorell, B. Quantitative reflection contrast microscopy of living cells. J. Cell. Biol. 1979, 82, 767-779. [CrossRef] [PubMed]

5. Fruin, J.T.; Idll, T.M.; Clarke, J.B.; Fowler, J.L.; Guthertz, L.S. Accuracy and Speed in Counting Agar Plates1. J. Food Prot. 1977, 40, 596-599. [CrossRef] [PubMed]

6. Haandbæk, N.; Bürgel, S.C.; Heer, F.; Hierlemann, A. Characterization of subcellular morphology of single yeast cells using high frequency microfluidic impedance cytometer. Lab Chip 2014, 14, 369-377. [CrossRef] [PubMed]

7. Krommenhoek, E.E.; Gardeniers, H.J.; Bomer, J.; Berg, A.V.D.; Li, X.; Ottens, M.; Van Der Wielen, L.; Van Dedem, G.; Van Leeuwen, M.; Van Gulik, W.; et al. Monitoring of yeast cell concentration using a micromachined impedance sensor. Sens. Actuators B Chem. 2006, 115, 384-389. [CrossRef]

8. Turolla, A.; Di Mauro, M.; Mezzera, L.; Antonelli, M.; Carminati, M. Development of a Miniaturized and Selective Impedance Sensor for Real-Time Slime Monitoring in Pipes and Tanks. Sens. Actuators B Chem. 2019, 281, 288-295. [CrossRef]

9. Suehiro, J.; Ohtsubo, A.; Hatano, T.; Hara, M. Selective detection of bacteria by a dielectrophoretic impedance measurement method using an antibody-immobilized electrode chip. Sens. Actuators B Chem. 2006, 119, 319-326. [CrossRef]

10. Gawad, S.; Schild, L.; Renaud, P. Micromachined impedance spectroscopy flow cytometer for cell analysis and particle sizing. Lab Chip 2001, 1, 76-82. [CrossRef] [PubMed]

11. Geddes, L.A.; Baker, L.E. Principles of Applied Biotent, Medical Instrumentation, 3rd ed.; Wiley: New York, NY, USA, 1989; pp. 566-576.

12. Felice, C.J.; Madrid, R.E.; Olivera, J.M.; Rotger, V.I.; Valentinuzzi, M.E. Impedance microbiology: Quantification of bacterial content in milk by means of capacitance growth curves. J. Microbiol. Methods 1999, 35, 37-42. [CrossRef]

13. Cady, P. Progress in Impedance Measurements in Microlayer-Biology. In Mechanizing Microbiology; Sharpe, A.N., Clark, D.S., Eds.; Thomas: Springfield, IL, USA, 1978; pp. 199-239.

14. Kiani, M.; Du, N.; Vogel, M.; Raff, J.; Hübner, U.; Skorupa, I.; Bürger, D.; Schulz, S.E.; Schmidt, O.G.; Schmidt, H. P-N Junction-Based Si Biochips with Ring Electrodes for Novel Biosensing Applications. Biosensors 2019, 9, 120. [CrossRef] [PubMed]

15. Kiani, M.; Du, N.; Vogel, M.; Raff, J.; Hübner, U.; Skorupa, I.; Bürger, D.; Schulz, S.E.; Schmidt, O.G.; Blaschke, D.; et al. Disturbing-Free Determination of Yeast Concentration in DI Water and in Glucose Using Impedance Biochips. Biosensors 2020, 10, 7. [CrossRef] [PubMed] 
16. Jungerman, J.A. Fourth-order uniform electric field from two charged rings. Rev. Sci. Instrum. 1984, 55, 1479. [CrossRef]

17. Scully, J.R.; Silverman, D.C.; Kendig, M.W. Electrochemical Impedance-Analysis and Interpretation; ASTM: Philadelphia, PA, USA, 1993; p. 54.

18. Fricke, H. The theory of Electrolyte Polarization. Philos. Mag. 1953, 14, 310-318. [CrossRef]

19. Kerrison, L. The capacitor. Stud. Q. J. 1933, 4, 100. [CrossRef]

20. Cole, K.S.; Cole, R.H. Dispersion and Absorption in Dielectrics I. Alternating Current Characteristics. J. Chem. Phys. 1941, 9, 341. [CrossRef]

21. McKubre, M.C.H.; Macdonald, D.D. Electronic Instrumentation for Electrochemical Studies. In $A$ Comprehensive Treatise of Electrochemistry; Bockris, J.O., Conway, B.E., Yeager, E., Eds.; Plenum Press: Boston, MA, USA, 1984.

22. Zandman, F.; Stein, S. A New Precision Film Resistor Exhibiting Bulk Properties. IEEE Trans. Compon. Parts 1964, 11, 107-119. [CrossRef]

23. Usui, Y. Equivalent Circuit of Distributed Constant Circuit and Transmission Equation. J. Jpn. Inst. Electron. Packag. 2018, 21, 311-316. [CrossRef]

24. Bauerle, J.E. Study of Solid Electrolyte Polarization by a Complex Admittance Method. J. Phys. Chem. Solids 1969, 30, 2657-2670. [CrossRef]

25. Sihvola, A. Electromagnetic Mixing Formulas and Applications; The Institute of Electrical Engineers: London, UK, 1999.

26. Barsoukov, E.; Ross, M.J. Impedance Spectroscopy: Theory, Experiment, and Applications; John Wiley \& Sons: Hoboken, NJ, USA, 2018.

27. Novoseleskii, M.; Gudina, N.N.; Fetistov, Y.I. Identical Equivalent Impedance Circuits. Sov. Electrochem. 1972, 8, 546-548.

(C) 2020 by the authors. Licensee MDPI, Basel, Switzerland. This article is an open access article distributed under the terms and conditions of the Creative Commons Attribution (CC BY) license (http://creativecommons.org/licenses/by/4.0/). 